\title{
Menuju Implementasi Flexible Working Arrangement Ideal Pasca Masa Covid-19
}

\author{
(Studi Praktek Terbaik Pada Kementrian Kelautan dan \\ Perikanan)
}

\author{
Dida Daniarsyah $^{1}$, Nova Dwi Rahayu ${ }^{1}$ \\ ${ }^{1}$ Kementerian Kelautan dan Perikanan, Jalan Medan Merdeka Timur Nomor 16, Jakarta
}

\begin{abstract}
This article tries to analyse the implementation of the Flexible Working Arrangement (FWA) and identify the ideal FWA model. The research problem raised in the ongoing FWA implementation that does not yet have a minimum FWA standard by academic or philosophical concepts. FWA at the Ministry of Maritime Affairs and Fisheries is suspected of being unplanned and aims merely to prevent employees from contracting co-19. The research method uses a descriptive qualitative approach. Primary data sourced from interviews, observations, documentation. The study results concluded that FWA implementation is still limited to moving attendance from the office to the home through the WFH scheme and tends to be forced. Without planning, employees do not understand the ideal WFH concept. WFH that has been taking place at KKP can be adequately developed into an ASN work system model with broader schemes such as job sharing and flexi-time. The success of the WFH implementation depends very much on supporting mobile and HP mobile devices for Zoom Applications and the like, the availability of internet data packages, and the network infrastructure condition at the WFH location. The suggestions from the study results are psychological needs in managing work behavior to be productive by formulating an ideal FWA model that considers factors, impacts, implementation, and benefits to achieve effective, efficient, productive, and contributed.
\end{abstract}

Keywords: Flexible Working Arrangement, Implementation, FWA Model

\section{Pendahuluan}

Kebijakan Presiden terhadap sistem kerja Aparatur Sipil Negara pada Kementerian dan Lembaga yang berlokasi di zona pandemik untuk bekerja dari rumah merupakan langkah taktis dan strategis dalam memutus rantai penyebaran virus covid-19. Hal ini ditunjukkan dengan Surat Edaran Menpan dan RB Nomor 19 Tahun 2020 tentang penyesuaian sistem kerja sebagaimana diubah keempat kali dengan SE nomor 58 tahun 2020 tentang Sistem Kerja Pegawai Aparatur Sipil Negara Dalam Tatanan Normal Baru.

Hikmah bencana virus covid19 yaitu penerapan sistem kerja dari rumah dapat dilaksanakan walaupun dengan berbagai catatan yang terkesan negatif, seperti kinerja menurun drastis, tidak produktif, 
berimbas pada pelayanan publik menurun dan pertumbuhan ekonomi menurun. Data World Bank menunjukkan pertumbuhan ekonomi RI masa pandemik 0\% (Kompas, 3 Juni 2020). Di sisi lain, ASN masih dapat beraktivitas melaksanakan tugas dan fungsinya dari rumah dengan metode WorkFrom Home (WFH). WFH merupakan salah satu atribusi fleksibilitas pengelolaan bekerja (Flekxible Working Arrangement/WFA) yaitu dengan memindahkan kehadiran dari kantor ke rumah.

Praktek WFH yang dilaksanakan diberbagai instansi Kementerian, dari hasil pengamatan secara fisik dan penelusuran dari berbagai media sosial harus diakui tidak berjalan secara normal sebagaimana aktivitas yang terjadi sebelum pandemik. Indikasi ini dapat diasumsikan baik dari dimensi produktivitas, pelayanan, dan proses bisnis. Satu diantara Kementerian yang mengimplementasikan WFH yaitu Kementerian Kelautan dan Perikanan. Akan tetapi sebagai trigger atau pemacu awal implementasi FWA di masa pandemik memiliki potensi efektif untuk dikembangkan sebagai alternatif model sistem kerja ASN pasca pandemik.

Mengamati praktek implementasi FWA pada KKP di masa pandemik harus diakui masih belum memiliki standar minimal FWA sesuai dengan konsep akademis atau filosofis. Suzan Lewis (Lewis, 2003) mengemukakan flexible working arrangements (FWAs), that is organizational policies and practices that enable employees to vary, at least to some extent, when and/or where they work or to otherwise diverge from traditional working hours. They include, for example, flexitime, term time working, part-time or reduced hours, job sharing, career breaks, family-related and other leaves, compressed work weeks and teleworking. Dengan kata lain FWA adalah kebijakan dan praktik organisasi yang memungkinkan karyawan berbeda-beda, setidaknya sampai batas tertentu, kapan dan atau di mana mereka bekerja atau berbeda dari jam kerja tradisional. misalnya, waktu istirahat, kerja jangka waktu tertentu, paruh waktu atau jam kerja berkurang, berbagi pekerjaan, istirahat karier, daun yang terkait keluarga dan lainnya, minggu kerja yang diperketat, dan teleworking. Implementasi Flexible Working Arrangement (FWA) diprediksi akan menjadi sebuah solusi untuk mengakomodasi dukungan kepada pegawai atau karyawan karena penelitian menemukan banyak dampak positif dari implementasi FWA pada organisasi. Flexible Work Arrangement (FWA) didefinisikan sebagai sebuah alternatif pilihan yang diberikan oleh organisasi kepada pegawainya untuk menentukan jadwal dan tempat bekerja (Rau \& Hyland, 2002). Sehingga FWA lebih berfokus kepada ouput atau hasil daripada prosedur kerja (Spreitzer, Cameron, \& Garrett, 2017). Implementasi FWA dalam konteks organisasi dapat dilihat dalam beberapa bentuk, seperti telecommuting, flexible time, dan job sharing. (Allen, Johnson, Kiburz, \& Shockley, 2013) Flextime dan telecommuting merupakan dua pilihan yang relatif banyak digunakan oleh pegawai di beberapa organisasi. Telecommuting memungkinkan 
karyawan untuk melakukan pekerjaan kantor dari tempat lain dengan bantuan teknologi (misalnya, komputer dan internet) dan flextime memungkinkan karyawan untuk memilih waktu memulai dan menyelesaikan pekerjaan berdasarkan persyaratan waktu yang telah dibuat oleh organisasi (Allen, Golden, \& Shockley, 2015). FWA berpengaruh pada peningkatan produktivitas karyawan sehingga dapat meningkatkan keuntungan yang akan diperoleh organisasi. FWA dapat meningkatkan kepuasan kerja, komitmen organisasi, work life balance dan mendorong karyawan untuk memberikan performa terbaik. (Kelliher, Kelliher, \& Anderson, 2009; Shagvaliyeva \& Yazdanifard, 2014) Namun, beberapa penelitian menemukan bahwa penerapan FWA di negara maju berdampak positif sementara pada negara berkembang justru berdampak negatif. (Kossek, Thompson, \& Lautsch, 2015; Raffaele \& Connell, 2016) Indonesia termasuk salah satu negara berkembang, sehingga dampak penerapan FWA pada karyawan di Indonesia masih perlu untuk dilakukan. Salah satu perusahaan yang menerapkan FWA di Indonesia adalah Praxis. Praxis sebagai perusahaan lokal yang bergerak di bidang agensi public relations telah mulai menerapkan FWA dalam bentuk telecomuting (Praxis, 2018). Implementasi FWA memberikan pengaruh langsung terhadap peningkatan employee engagement. Employee engagement adalah sebuah kondisi ketika karyawan hadir secara psikologis dalam melakukan pekerjaannya yang dapat dilihat dari intensitas dan arah kognitif, emosional dan arah energy. (Kahn \& Kahn, 2013; Shuck, 2011)
Selain memberikan dampak positif, beberapa penelitian juga menemukan bahwa implementasi FWA memiliki dampak negatif. Misalnya bentuk telecomuting membuat tidak adanya batasan antara tempat kerja dan rumah sehingga dapat meningkatkan family stress, work-family conflicts, dan meningkatkan perilaku kontraproduktif (Gajendran, Harrison, \& Delaney-klinger, 2014). Dampak penerapan FWA dalam organisasi berhubungan erat dengan tingkat pengambilan keputusan etis karyawan (Ethical Decision Making).

Berangkat dari uraian fakta di atas, hal ini adalah suatu fenomena untuk kajian atau penelitian tentang bagaimana Implementasi FWA di KKP dalam masa pandemik dan bagaimana FWA efektif menjadi salah satu model sistem kerja ASN pada Kementerian Kelautan dan Perikanan.

\section{Metode Penelitian}

Penelitian ini menggunakan pendekatan kualitatif serta dengan jenis deskriptif. Melalui pendekatan kualitatif maka penelitian ini ditujukan untuk menggambarkan keadaan yang sesungguhnya secara rinci dan aktual serta disesuaikan dengan masalah dan tujuan penelitian. Ini digunakan dengan alasan bahwa fenomena yang diteliti memerlukan deskripsi dan analisa yang mendalam sehingga diharapkan dalam penelitian dapat ditemukan berbagai jawaban dan dapat mengungkapkan kejadian yang sesungguhnya di lapangan.

Pendekatan kualitatif ini cocok dipakai untuk mengkaji fenomena sosial yang unik sebab pendekatan ini luwes dan tidak ketat sehingga 
banyak alternatif yang dapat digunakan untuk menjawab fenomena yang terjadi di lapangan. Sesuai dengan fokus dan rumusan masalah penelitian maka penelitian yang dilakukan berlokasi di Kementerian Kelautan dan Perikanan. Alasan penentuan lokasi penelitian di KKP karena memiliki prestasi dalam pengelolaan manajemen sumber daya manusia berbasis sistem merit dari Ketua Komisi Aparatur Sipil Negara (KASN). Sehingga informasi terkait pelaksanaan implementasi FWA memiliki bobot yang akuntabel dan validitas data terjamin.

Penelitian ini sumber data utama yang digunakan adalah data primer, yakni berupa kata-kata lisan baik yang bersumber dari wawancara mendalam dengan informan penelitian. Selain itu ditambah dengan dukungan data sekunder, yakni berupa data dari dokumenter. Menurut Bogdan dan Taylor (Taylor, 1993) bahwa sumber data dalam pendekatan kualitatif dapat berupa bukti- bukti bagi kasus yang berasal dari dokumen, rekaman arsip, wawancara, observasi langsung, observasi pameran dan perangkat fisik.

Berdasarkan sumber data tersebut maka teknik pengumpulan data yang digunakan dalam penelitian ini adalah:

1) Wawancara, dalam hal ini peneliti melakukan wawancara mendalam dalam bentuk pertanyaan bebas dengan berbagai informan baik yang terlibat langsung maupun tidak langsung dalam Implementasi pelaksanaan FWA.

2) Observasi, dalam hal ini peneliti melakukan pengamatan terhadap objek penelitian yaitu mengenai tingkat kehadiran ASN.

3) Dokumentasi, dalam hal ini Untuk melengkapi penelitian ini perlu ditunjang dengan data dokumenter. Ini dilakukan peneliti dengan cara mengumpulkan data yang relevan dan sudah terhimpun dan dikelola oleh pihak Pusdatin, Biro Kepegawaian, Biro Keuangan, Biro Hukum dan Organisasi, dan Satuan Kerja Pelayanan Publik Karantina Ikan.

Informan yang dipakai dalam penelitian ini ditentukan secara sengaja (purposive). Yaitu orangorang yang memiliki pengetahuan dan pemahaman mengenai fokus penelitian mengenai Implementasi FWA, dan Pelayanan Publik. Sehingga informan dalam penelitian ini adalah: Pejabat Biro SDM, Pejabat Biro Hukum dan Organisasi, Pejabat Biro Keuangan, Pengelola Pusdatin, Pengelola Pelayanan Publik satuan Karantina Ikan.

Untuk melakukan analisis terhadap data yang diperoleh dari hasil wawancara, observasi dan dokumentasi peneliti menggunakan teknik analisis kualitatif dengan mengadopsi teknik yang ditawarkan oleh Miles dan Hubermen. Menurut Miles dan Hubermen (dalam Sugiyono, 2011) bahwa aktivitas dalam analisis data kualitatif dilakukan secara interaktif dan berlangsung secara terus menerus pada setiap tahap penelitian sehingga sampai tuntas dan penggalian datanya sampai mendapatkan informasi yang paling tepat. 


\section{Hasil dan Pembahasan}

Secara teoritis FWA dalam pandangan Suzan Lewis (2003) mengemukakan flexible working arrangements (FWAs), that is organizational policies and practices that enable employees to vary, at least to some extent, when and/or where they work or to otherwise diverge from traditional working hours. They include, for example, flexitime, term time working, parttime or reduced hours, job sharing, career breaks, family-related and other leaves, compressed work weeks and teleworking.

Dengan kata lain FWA adalah kebijakan dan praktik organisasi yang memungkinkan karyawan berbedabeda, setidaknya sampai batas tertentu, kapan dan / atau di mana mereka bekerja atau berbeda dari jam kerja tradisional. misalnya, waktu istirahat, kerja jangka waktu tertentu, paruh waktu atau jam kerja berkurang, berbagi pekerjaan, istirahat karier, dan yang terkait keluarga dan lainnya, minggu kerja yang diperketat, dan teleworking.

Dari hasil penelitian dilapangan ditemukan data dan fakta yang menjelaskan implementasi FWA di KKP.

\section{Human Capital KKP}

ASN Kementerian Kelautan dan Perikanan merupakan salah satu ASN yang turut serta dalam penerapan WFH dengan kondisi adanya bencana virus corona-19. Dari hasil penelitian profile ASN KKP sangat didominasi oleh pegawai yang memiliki usia produktif dan jenjang pendidikannya mayoritas berpendidikan S1-S2. Data dapat dijelaskan dalam gambar 1 . sebagai berikut,
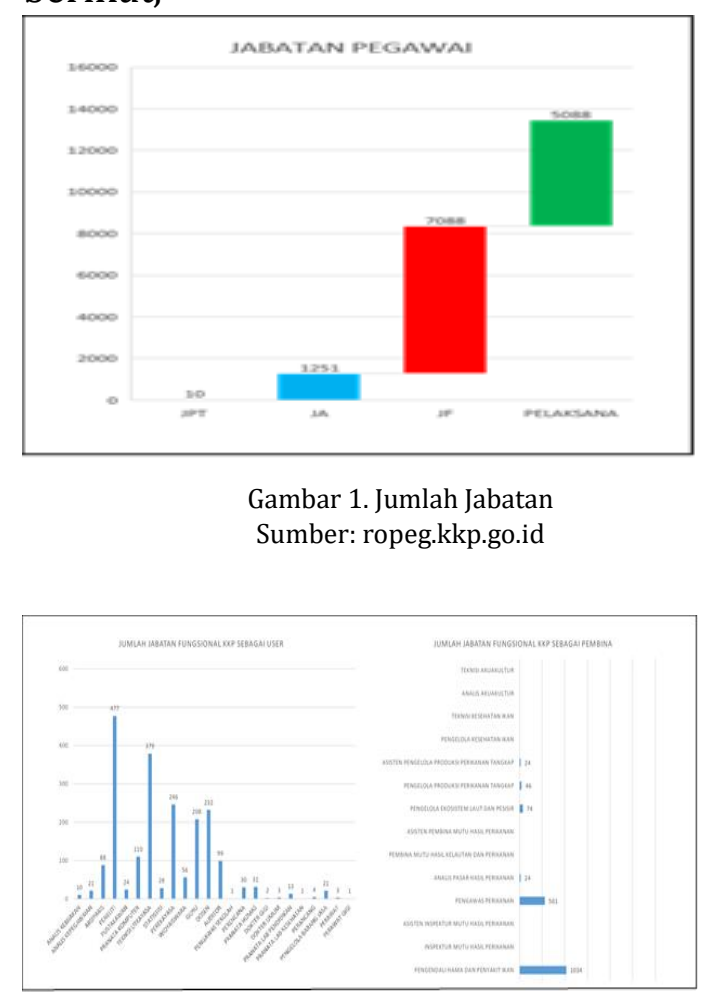

Gambar 2. Jumlah Jenis Jabatan Fungsional Sumber: ropeg.kkp.go.id

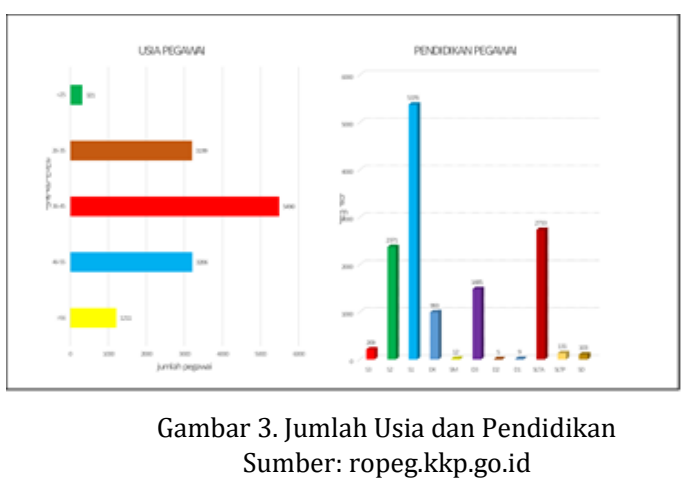

Jumlah PNS KKP sebanyak 13.427 orang, terdiri dari pejabat manajerial 1.251 orang (akan berkurang pasca Transformasi jabatan Administrasi), jumlah JFT 7088 orang, dan staf pelaksana 5.088 orang, Jumlah Pegawai Pemerintah Non PNS sebanyak 4879, Jumlah 
CPNS sebanyak 436 orang. KKP memiliki 17 jenis jabatan fungsional sebagai pembina dan menggunakan 22 jenis jabatan fungsional sebagai instansi pengguna. Usia produktif ASN KKP hampir $60 \%$ diantara usia 25 - 55 tahun. Kondisi ini merupakan human capital yang potensial untuk berkontribusi terhadap organisasi.

\section{WFH dan Pelaporan Kinerja}

Implementasi WFH kaitannya dengan kinerja Pegawai KKP dapat dilihat pada Gambar 4. Hampir 98 persen pegawai KKP melaporkan kinerjanya tiap bulan. Adapun 2 persen pegawai melaporkan secara manual karena statusnya dalam keadaan tugas belajar, cuti di luar tanggungan Negara, Cuti melahirkan dan cuti alasan Sakit. Secara rinci dilaporkan bahwa pelaporan kinerja tiap bulan tersebut merupakan kebijakan KKP yang diberlakukan kepada pegawainya. Data pada gambar 4. Menunjukkan kondisi dari awal bulan Januari sampai dengan Juni 2020 tetap stabil konsisten di kisaran 98 - 99 persen.

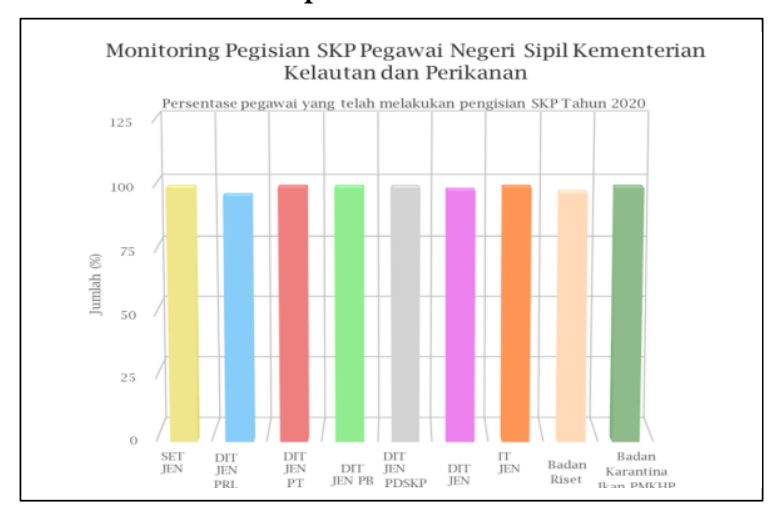

Gambar 4. Monitoring laporan Kinerja tiap bulan Sumber: Prestasikerja.kkp.go.id

\section{WFH dan Pelaporan Kesehatan}

Selain pelaporan kinerja, pegawai KKP dituntut melaporkan kesehatnnya perhari dan share lokasi rumahnya tiap hari sebagi wujud komitmen melaksanakan WFH dan kewajiban melaporkan kesehatan berkaitan dengan pendeteksian kondisi kesehatan pegawai dari bahaya terkena virus Covid-19. Hasil penelitian menunjukkan data pada gambar 5. Menjelaskan bahwa pelaporan monitoring kesehatan tingkat eselon I partisipasi pegawai melaporkan kondisi kesehatannya secara rutin tiap hari sekitar 70 persen. Artinya sebagian besar pegawai memberikan informasi kesehatannya. Sekurangnya, pegawai berpandangan tidak perlu melaporkan kesehatannya karena merasa sehat. Ada yang berpendapat bahwa karena aplikasi pengisian dengan google form terlalu rigid pertanyaannya akhirnya pengisian form pelaporan kesehatan cenderung diabaikan oleh pegawai. Memperhatikan fakta ini apabila pegawai ingin berpartisipasi seluruhnya maka harus ada instruksi atau ketentuan yang mewajibkan pegawai melaporkan kesehatannya, dan apabila tidak melaporkan maka sangsi akan dikenakan kepada pegawai yang tidak peduli atau mengabaikannya. 


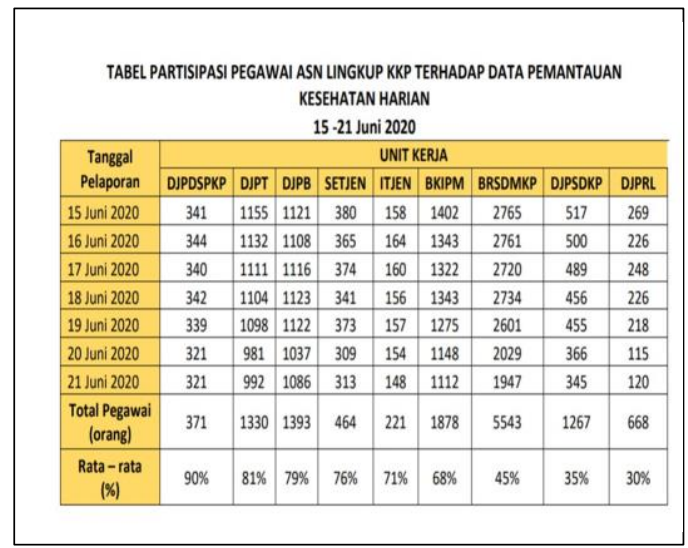

Gambar 5. Data Pelaporan Kesehatan Sumber: KKP,2020

\section{WFH dan Dukungan Financial}

Praktek implementasi WFH di KKP mendapat dukungan administrasi keuangan sangat tinggi. Hal ini ditunjukkan dengan adanya dokumen Surat Direktur Jenderal Perbendaharaan, Kemenkeu Nomor S-369/PB/2020

Perihal

Pemutakhiran Akun Belanja Dalam Rangka Penanganan COVID-19, Peraturan Menteri Keuangan Nomor 38/PMK.02/2020 tentang Pelaksanaan Kebijakan Keuangan Negara Untuk Penanganan Pandemi Corona Virus Disease 2019 (COVID-19) dan/atau Menghadapi Ancaman Yang Membahayakan Perekonomian Nasional dan/atau Stabilitas Sistem Keuangan, Surat Edaran Direktur Jenderal Anggaran Nomor SE1/AG/2020 tentang Penjelasan Standar Biaya Masukan dalam Pelaksanaan Work From Home (WFH). Dukungan regulasi dari Kementerian Keuangan dalam upaya meringankan beban biaya melaksanakan aktivitas pekerjaan dengan telecommuting atau video conference yang membutuhkan kuota atau paket data bahkan sewa paket internet di rumah masing-masing.

\section{WFH dan Pelayanan Publik}

Walaupun sistem kerja WFH, KKP tetap melaksanakan tugas pelayanan publik secara langsung walaupun dengan persentase terbatas sekitar $30 \%$ dan dengan tindakan protokol kesehatan. Ketentuan ini tertulis pada Surat Edaran Menteri Kelautan dan Perikanan Nomor B.308/MEN$\mathrm{KP} / \mathrm{VI} / 2020$ tentang penyesuaian system kerja dalam tatanan normal baru di lingkungan KKP.

Data atau fakta-fakta pelayanan masih berjalan ditunjukkan dengan dokumentasi video yang termuat dalam link https://youtu.be/iEeRe4qL9-Y pekan pelayanan publik karantina ikan Yogjakarta, https://youtu.be/jUr3uLPXDYY pekan pelayanan publik di Semarang. https://www.youtube.com/watch?v= 70ybPE0kVZM pekan pelayanan publik di Makassar. Dukungan regulasi terkait pelayanan publik yang dilaksanakan KKP sudah sangat kuat. Hal ini ditunjukkan dengan Kepmen.KP. NO. 32 / 2014 tentang Pelayanan Publik di lingkup KKP sebagai tindak lanjut Undang-undang Nomor 25 tahun 2009 tentang Pelayanan Publik.

Aktivitas yang terekam dalam dokumentasi tersebut menjadi bukti bahwa KKP tetap berkomitmen melaksanakan pelayanan publik dalam keadaan apapun. Fakta lainya ditemukan dengan telah diaturnya teknis pelayanan publik dalam 
keadaan pandemik. Gambar 6. Menjelaskan tata cara pelayanan public masa new normal.

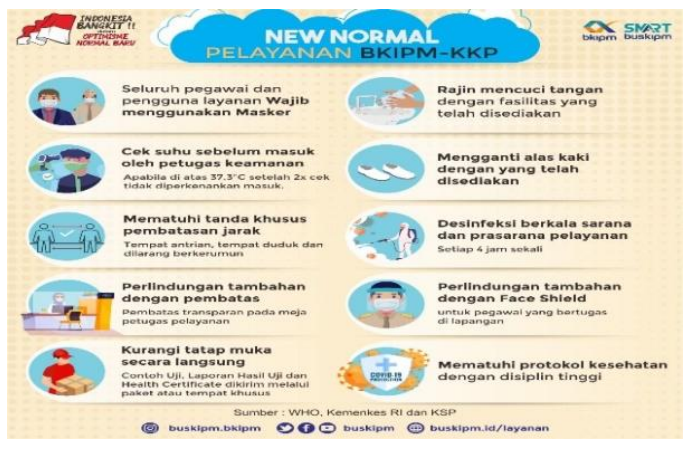

Gambar 6. Teknis Pelayanan Publik Masa New Normal

Sumber: BKIPMHP,2020

\section{WFH dan Dukungan Infrastruktur Teknologi}

Perkembangan

teknologi

informasi berbasis aplikasi menjadi faktor pendukung keberhasilan WFH. Sehingga selektifitas dalam memilih aplikasi yang digunakan sangat tergantung dari praktek pekerjaan yang akan dilakukan. KKP telah memanfaatkan aplikasi antara lain pertama WhatsApp, Aplikasi pesan instan ini penting untuk menjalin komunikasi sesama rekan kerja. Bahkan walaupun sedang tidak kerja dari rumah pun, aplikasi ini sering digunakan. Melalui WhatsApp, bisa melakukan koordinasi dengan rekan kerja, baik melalui berkirim pesan teks, foto, atau melalui video call hingga empat orang secara bersamaan. Kedua Zoom, Aplikasi Zoom menghadirkan fitur yang maksimal untuk melakukan video conference, sama seperti Google Hangout. Semua tim bisa melakukan komunikasi video secara bersamaan dengan kualitas video dan audio yang baik. Aplikasi ini bisa digunakan di perangkat mobile dan desktop komputer atau laptop.
Tidak hanya fitur video conference, Zoom juga memiliki fitur lainnya, seperti kirim pesan teks, foto, audio, dan video.

Terkait dukungan teknologi ini membutuhkan perangkat hardware yang support terhadap aplikasi yang digunakan. Akan tetapi pada umumnya pegawai di KKP telah memiliki perangkat yang support baik HP ataupun Laptop. Sehingga WFH tetap produktif dan stay safe.

\section{Menuju Model FWA ideal}

Implementasi WFH di KKP dapat dijadikan input atau salah satu best practice menuju penerapan system kerja melalui pendekatan FWA yang ideal di Indonesia. Beberapa alasan yang sangat mendukung penerapan FWA di Indonesia dapat dijelaskan melalui gambar model dibawah ini :

\begin{tabular}{|l|}
\hline FAKTOR: \\
O Tuntutan efektivitas \\
kinerja Organisasi \\
O Tingginya tingkat \\
persaingan talenta terbaik \\
O Kebutuhan SDM \\
berkualitas dan Produktif \\
O Tuntutan work-life balance \\
O Revolusi industry 4.0 dan \\
Society 5.0 dan potensi \\
generasi milineal \\
O Kemajuan teknologi dan \\
fleksibilitas interaksi \\
o berkurangnya \\
sosial dalam keluarga dan \\
masyarakat \\
O Akses menuju kantor tidak \\
efesien, pemborosan \\
tersendiri (waktu, tenaga, \\
pikiran, stress)
\end{tabular}

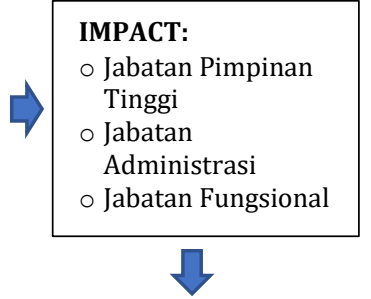

IMPLEMENTASI FWA:

- Analisis jenis pekerjaan/jabatan dalam skema FWA

- Penysunan proses bisnis FWA

- Trial and eror FWA

- Deregulasi pengaturan Jam kerja dan Disiplin PNS, financial

\section{BENEFIT:}

- Individu Pegawai

- Kesejahteraan Pegawai

- Cost economy

- Maintance infrastruktur teknologi

- Social dan lingkungan

Gambar 7. Model FWA Ideal

Sumber: diolah sendiri, (Modifikasi Ramune Ciarniene et.all, 2018; Ernawati, 
Model di atas dapat dijelaskan bahwa menuju FWA yang ideal pada sebuah Kementerian atau Lembaga/organisasi diawali dengan melihat faktor-faktor yang menjadi penentu urgensi kebutuhan system kerja dengan skema FWA. Kemudian memperhatikan impact atau manusia yang yangan menjadi dampak FWA. Selanjutnya dalam implementasinya dilakukan beberapa tahapan di mulai dari analisis pekerjaan dan jabatan yang dapat diterapkan melalui skema kebijakan FWA, monitoring dan evaluasi wajib dilakukan dalam upaya penyempurnaan implementasi FWA.

\section{Kesimpulan}

Implementasi FWA yang ideal membutuhkan dukungan dari berbagai dimensi seperti faktor penyebab, implikasi pada yang terdampak, implementasi yang terencana sehingga menghasilkan benefit yang menguntungkan semua pihak.

Praktek terbaik FWA yang dilaksanakan di KKP harus diakui masih sebatas memindahkan kehadiran dari kantor ke rumah melalui skema WFH. Akan tetapi, dapat dimaklumi bahwa kebijakan ini lahir dari proses kebijakan yang didesain bukan untuk real kondisi FWA ideal, melainkan dalam upaya memutus suspect penyebaran covid19.

WFH yang telah berlangsung di KKP berpotensi efektif untuk dikembangkan menjadi sebuah model sistem kerja ASN dengan skema lebih luas antara lain job sharing dan flexitime.

Keberhasilan implementasi

WFH sangat tergantung pada supporting perangkat keras seperti perangkat mobile/HP dan Laptop terhadap Aplikasi Zoom dan sejenisnya, ketersedian paket data internet dan kondisi infrastruktur jaringan pada lokasi WFH.

Adapun saran dari hasil penelitian adalah kebutuhan psikologis dalam menata perilaku kerja agar produktif dengan merumuskan model FWA ideal yang mempertimbangkan faktor, impact, implementasi dan benefit guna meraih efektif, efesien, produktif dan kontributif.

\section{Daftar Referensi}

Allen, T. D., Golden, T. D., \& Shockley, K. M. (2015). How Effective Is Telecommuting? Assessing the Status of Our Scientific Findings. https://doi.org/10.1177/15291 00615593273

Allen, T. D., Johnson, R. C., Kiburz, K. M., \& Shockley, K. M. (2013). Work-family conflict and flexible work arrangements: Deconstructing flexibility. Personnel Psychology. Allen, Tammy D.: University of South Florida, Department of Psychology, 4202 E. Fowler Ave, Tampa, FL, US, 33620, tallen@mail.usf.edu: WileyBlackwell Publishing Ltd. https://doi.org/10.1111/peps.1 2012

Dewi Fransiska Simanjuntak dkk. 2019. Pengaruh Flexible Work Arrangement Terhadap Ethical Decision Making : Peran Employee Engagement Sebagai Mediator, Jurnal Diversita, 5 (1) Juni (2019) ISSN 2461-1263 (Print) ISSN 2580-6793 (Online) DOI: http://dx.doi.org/10.31289/div ersita.v5i1.2327. 
Erna Irawati. 2019. Menyongsong Flexible Working Arrangement Bagi ASN Jurnal Analis Kebijakan | Vol. 3 No. 1 Tahun 2019, Lembaga Administrasi Negara

Gajendran, R. S., Harrison, D. A., \& Delaney-klinger, K. (2014). ARE TELECOMMUTERS REMOTELY GOOD CITIZENS ? UNPACKING TELECOMMUTING' 'S EFFECTS ON PERFORMANCE VIA I-DEALS AND JOB RESOURCES, 1-41. https://doi.org/10.1111/peps.1 2082

Kahn, W. A., \& Kahn, W. A. (2013). Psychological Conditions of Personal Engagement and Disengagement at Work. Academy of Management Journal, 33(4), 692-724.

Kelliher, C., Kelliher, C., \& Anderson, D. (2009). Doing more with less? Flexible working practices and the intensification of work. Human Relations, (May 2014). https://doi.org/10.1177/00187 26709349199

Kossek, E. E., Thompson, R. ., \& Lautsch, B. A. (2015). Balanced Workplace Flexibility: Avoiding the Traps, 57(4), 5-25. https://doi.org/https://doi.org/ 10.1525/cmr.2015.57.4.5

Lewis, S. (2003). FLEXIBLE WORKING ARRANGEMENTS:

IMPLEMENTATION, OUTCOMES, AND MANAGEMENT (Vol. 18, pp. 1-28). Manchester Metropolitan University.

Raffaele, C., \& Connell, J. (2016). Telecommuting and Co-Working Communities: What Are the Implications for Individual and
Organizational Flexibility?

Rau, B. L., \& Hyland, M. A. M. (2002). ROLE CONFLICT AND FLEXIBLE WORK ARRANGEMENTS: THE EFFECTS ON APPLICANT ATTRACTION. Personnel Psychology, 55(1). https://doi.org/https://doi.org/ 10.1111/j.17446570.2002.tb00105.x

Shagvaliyeva, S., \& Yazdanifard, R. (2014). Impact of Flexible Working Hours on Work-Life Balance, 2014(January), 20-23.

Shuck, B. (2011). Employee Engagement: An Examination of Antecedent and Outcome Variables, (September). https://doi.org/10.1080/13678 868.2011.601587

Spreitzer, G. M., Cameron, L., \& Garrett, L. (2017). Alternative Work Arrangements: Two Images of the New World of Work. Annual Review of Organizational Psychology and Organizational Behavior, 4473(499), 473-499. https://doi.org/https://doi.org /10.1146/annurev-orgpsych032516-113332

Idiagbon-Oke, M., \& Oke, A. (2011). Implementing innovative flexible work practices in Nigerian local firms: Implications for management of change in lessdeveloped countries. Journal of Occupational and Organizational Psychology, 84, 518-543. doi:10.1111/j.20448325.2011.02021.x

Taylor, R. (1993). Kualitatif: DasarDasar Penelitian. Surabaya: Usaha Nasional. 
Jones, T. M. (1991). Ethical decision making by individuals in organizations: An issuecontingent model. Academy of Management, 16, 366-395.

Miles, Matthew B. \& A. Michel Huberman.1992. Analisis Data Kualitatif, UI-Press, Jakarta.Praxis. (2018). Praxis Indonesia [Web post].Retrieved from

Ramune Ciarniene et.all., 2018. Implementation of Flexible Work Arrangements for Sustainable Development. European Journal of Sustainable Development (2018), 7, 4, 11-21, Doi: 10.14207/ejsd.2018.v7n4p11 ISSN: 2239-5938 